\title{
Kvalitatiivsed muutused fraseoloogias: olemus ja suunajad ${ }^{1}$
}

\author{
Katre Õim, Asta Õim
}

Teesid: Artiklis on vaatluse all sõnavaraüksuste kvalitatiivne muutumine kui keele arenguprotsessi loomulik osa. Selgitatakse fraseologismide tähenduse muutumise süsteemipärasust. Selleks on valitud väljend läheb nagu lepase reega - keeleajalooliselt vana genuiinne ütlus, mis on hästi tuntud nii eesti murde-, kõne- kui ka kirjakeeles ja mille tähendus on läbi teinud suurima võimaliku kvalitatiivse muutuse. Algselt oli selle fraseologismi kujundi fookuses tõenäoliselt ree valmistamise materjal ja ütlus tähendas negatiivset ('halvasti edenema'vms). Suhteliselt lühikese aja jooksul on kujundi keskmesse nihkunud regi ja väljendi tähendus muutunud positiivseks ('hästi edenema'vms). Kujundi ümbermõtestamises on oma osa mänginud lepapuu mentaliteedi muutumine, kuid olulisem on kujunditekke taustsüsteem ja liikumissündmuse motivatsioon.

Märksõnad: aspekt, fraseoloogia, kognitiivne keeleteadus, kujundskeem, liikumissündmus, mõistemetafoor

\section{Sissejuhatuseks}

Sõnavaraüksuste kvalitatiivne muutumine on iga keele arenguprotsessi loomulik osa, mida põhjustavad nii keelesised kui ka keelevälised tegurid. Fraseologismid kui sisult ja vormilt klišeelisemad keeleüksused ei ole nii altid muutuma kui lekseemid. Samas on selge, et näiteks tähendusmuutused leiavad aset püsiväljendeiski. Valisime muutumise süsteemipärasuse selgitamiseks väljendi läheb nagu lepase reega ja seda mitmel põhjusel: 1) tegemist võib olla keeleajalooliselt vana genuiinse väljendiga, mille taolist ei leia Eesti lähinaabrite juurest ega kaugematest keeltest ${ }^{2}$ - see aitab elimineerida sisumuutuste keelevälised mõjurid; 2) väljend on hästi tuntud nii eesti murde-, kõne- kui ka kirjakeeles, 3) väljend on läbi teinud suurima võimaliku kvalitatiivse muutuse - selle algne tähendus 'halvasti edenema' on asendunud vastupidise tähendusega 'hästi edenema'. 
Artikkel koosneb kahest poolest. Kõigepealt on tähelepanu all ütluse identiteet: selle algupära, levik, kujundimehhanism. Seejärel püüame kujundskeemide ja mõistemetafooride abil selgitada fraseologismi tähenduse vastupidiseks muutumise süsteemipärasust.

\section{Väljendi läheb nagu lepase reega päritolust ja kasutusest}

\section{ree- ja kelgu-kujundi algupära}

Läheb nagu lepase reega on eesti oma vana väljend, mille absoluutse vanuse kohta on siiski raske midagi täpsemat öelda (vt lähemalt A. Õim 2005). Tõenäoliselt on ütlus käibele läinud perioodil, mil võeti kasutusele vastav veovahend. Regi võis välja kujuneda kas 13. sajandil, mil tekkis massiline kiviveovajadus seoses kiviehitiste rajamisega, või juba esimesel aastatuhandel eKr, kui kindlustatud asulate rajamisel vajati kivide vedamiseks mingit veovahendit. Esialgu olid veoalusena kasutusel suvised adra- ja äkkekelgud, hiljem heina-, palgi-, käsikelgud. Madalrege tunnevad nii balti ja läänemeresoome rahvad kui ka nende germaani naabrid; ida- ja lõunapoolseil slaavi aladel on regi võõras (Viires 1980: 33 jj).

Balti rahvastel on ühine samatüveline reenimetus: leedu roges, läti ragavas, eesti regi, liivi reggõz. Sõna põlisust rõhutab ka baltisaksa Regge, Ragge, mis oli käibel kohaliku talupojaree nimetusena (Viires 1980: 46, 47). Julius Mägiste järgi ongi sõna regi baltisaksa või läänemeresoome päritolu (Mägiste 2000: 2442). Deminutiiviga reekene, lounaeesti riikene, reikene 'kelk' (Saareste III: 535) on eesti keeles nimetatud kelku - reest hilisemat ning väiksemat jalasveokit, mida kasutati pea samasuguses veofunktsioonis (Viires 1980: 39, 49). Sellele, et kelgus nähti väikest rege, osutab ilmselt ka tarind nagu noor regi (siin noor tähenduses 'väike' (Käi). Sõna kelk ise on laenatud rootsi keelest (Mägiste 2000: 767). Wiedemanni ree- ja kelguväljendite tõlkevastetes ei esine konkreetseid rege/kelku märkivaid sõnu Schleife või Schlitten (Bauerschlitten, Handschlitten) aga kordagi. Vene keeles tuntakse mitmesuguseid talvistele veovahenditele rajatud kujundlikke ütlemisi, kuid nende tähenduslikku seost vastavate eesti kujunditega on raske näha, vrd näiteks в свои сани не садись 'iga kingsepp jäägu oma liistude juurde'. Nähtavasti on see tingitud piirkondade mõnevõrra erinevast majandustegevusest. Ants Viirese (1980: 36-38) andmeil moodustasidki ree leviala Baltimaad, kus kasutati funktsioonilt harklohistiga sarnast madalrege, ning Ida-Euroopa, kus oli universaalne kodarregi. 


\section{Kujundi levik vanemas ja tänapäeva eesti keeles}

Ree ja kelgu kujundipere selgub olevat tänapäeva eesti kirjakeeles varjusurmas, välja arvatud paar väljendit. Nii ongi Eesti kirjakeele seletussõnaraamatus (EKSS) fraseologismina esitatud ainult läheb nagu lepase lepse reega, eestimuukeelsetes tõlkesõnaraamatutes on neist fikseeritud esimene variant. EKSSi sõnaartiklis regi ülekantud tähendust ei eristata, sellele osutatakse vaid tsitaatnäitega (vt näidet 1).

(1) Kuid mu kooli asjus polnud Joonas küll minuga ühel reel [=ühes nõus] (H. Sergo).

Tartu Ülikooli eesti kirjakeele korpuses 1890-1990 esineb läheb nagu lepase lepse reega kokku vähem kui 100 korda; kirjakeelsema variandi eelistamist neil juhtudel näha ei ole. Enim tuleb väljendit ette 1990. aastate II poole ja 2000. aastate ajakirjanduses; vanemates ja stiililt nõudlikemates tekstides on kasutus oluliselt harvem. Kuigi sageli ei ole seda fraseologismi kasutatud ka kirjakeele korpuse uuest meediast, s.o interneti jututubadest, uudisgruppidest, foorumitest ja kommentaaridest pärit tekstides. Muu ree- ja kelgu-fraseoloogia kasutamine paistab veel juhuslikum (vt näiteid 2 ja 3 ).

(2) Susserdasin omaette, salamisi lootsin reele tagasi saada, meenutab ta nutuseid aegu (Eesti_Ekspress_2000).

(3) Ta rakendab valimiskampaania suusarahva ree ette, ja Tallinna linnajuhid annavad kirjaliku nõusoleku Nõmmele suusakeskuse rajamiseks (Eesti_Ekspress_1999).

Kuigi Eesti murrete korpusest läheb nagu lepase lepse reega leida ei õnnestunud, kinnitab Eesti kõnekäändude ja fraseologismide andmebaas (EKFA) ${ }^{3}$ ree- ja kelgu-kujundi laia levikut eesti murretes (kokku 175 päringuvastust, vt näiteid 4-8). Vastavaid keelendeid on üles kirjutatud veel 1960.-1970. aastail, ka vanemad allikad, s.h Wiedemanni ja Saareste sõnaraamatud registreerivad neid hulganisti.

(4) Eks iga töö ole esti võeras, tahab harjuda, pärast läheb kui lepase reega (Pil). Lasep kui leppäse riegä, laseb juttu nii et vahet ei õleki. Mõned asjad valestab (Lüg).

(5) See oli üks kevade - tulime metsaveost, viimane pidu oli, vaat jää tee äärde - ei jooksnud regi ega ratas (Kul).

(6) Kuidas siis su oma eluregi libiseb, kus sa nü̈̈d oma elujärjega oled? (Pöi) Nüüd tema kelk ôieti jookseb 'nüüd on tal palju austajaid' (Wied). 
(7) Vea nagu vene kelku 'midagi enda järel lohistama, näiteks looma kohta, kes ei taha järele tulla või purjus inimese kohta, keda sõber püüab koju viia' (Jõh). Veab ikke kelku ka vahel 'valetab' (Mär).

(8) Ta on kui kelk järel pandud (Hää).

Seda enam äratab tähelepanu, et eesti kirjakeeles on sõnade regi ja kelk kujundlik kasutus võrreldes murrete jm argikeelega väga piiratud. Ei ole päris selge, miks see kujund ei ole elujõuliseks osutunud. Üks põhjus võib olla inimeste elutingimuste muutumine; esemete kadumisega hääbuvad ajapikku ka mõisted ja sõnad. Regi ja kelk kui veovahendid on tänapäevaks oma praktilise otstarbe suuresti kaotanud, nende funktsioon on muutunud - kelku tuntakse rohkem laste sõidutamise ning lõbusõidu- ja spordivahendina. Nii ei saa öelda, et regi ja kelk kui sellised oleks tänapäeva inimestele täiesti tundmatud. Pole võimatu, et sõnadega regi, kelk jmt ei tähistata mentaalseid nähtusi (elujärg, mõttelaad, inimsuhted jms) enam kuigi sageli nende tarbeesemete aktuaalsuse taandumise tõttu. S.t muutused igapäevaelus avalduvad üsna pea meie mõtlemises ja sellest tulenevalt ka keeles. Samas tundub see otsitud põhjus, kui meenutada, et paljud teised vanad kujundid, näiteks piibliväljendite omad on sarnaste tingimuste juures säilinud. Oletuse lükkab ümber seegi, et tänapäeva suulises eesti keeles on ree- ja kelgu-väljendid päris tavalised, kontekstis arusaadavad ja asjakohased. Olgu selle kinnituseks kasvõi tuntud treener Andres Sõberi värvikas keelepruuk (saime kelgu peale, olime kelgus eduka korvpallikohtumise kohta) või interneti-otsingu vastuste rohkus (Google'i otsimootoriga üle 10000 vastuse, vt näiteid 9-12).

(9) Siis on mehel uuesti ree peale saamiseks ilmselt vajalik läbi teha ... Ei pruugi me suuta enam selle ree peale end upitadagi. Proovitakse riigikaitse ree peale kontvõõraks sokutada. Maadevahetajate ree peale üritas hüpata ka Rein Kilk. ... hüpanud moodsa nu-jazzi ree peale.

(10) Mart Laar tagasi reel. Tolerantsuse reel Mika on usinalt õppinud saksa ja türgi keelt. Rehepapid suurel NATO reel. Miks Sa siis ise olid nii rahvarindelane kui eestikongreslane, igaks juhuks kahel reel? Vana hea ree peal liuglev hirmusid külvav kooliinspektor. Mis seal salata, eks me ole palju aastaid sõitnud Jaan Tätte “mõnusa ree" peal, tänu temale on nii mitmedki teised meie autorid suurde maailma jõudnud. Kuulsa nime kelgul üritatakse kohalike võimukandjate ustest sisse liuelda. Vaata ikka, mees, kelle kelgu peal istud. Ega kõik või ühe kelgu peal sõita. 
(11) Oma riigi saamine on meil kõike nii kiirelt ja põhjalikult muutnud, et annab ikka ree peal püsida. Neil ei õnnestunud enam ree peal püsida ja et pärast viimaseid Riigikogu valimisi langesid nad Eestit valitsevast poliitkartellist sootuks välja. Kaotajate poolel hoidis oma tiimi ree peal Martti Varusk 26 punktiga.

(12) Kui keegi hakkab vahepeal ree pealt maha kolima, tekitab see kindlasti probleeme. Môistsin, et ta on ree pealt maas.

Diagramm 1 võtab üldistavalt kokku väljendi läheb nagu lepase lepse reega kasutuse sageduse, aja ning suhtlussituatsiooni vaatepunktist. Ebaproportsionaalsete absoluutarvude võrdlemiseks jagasime kirjakeele korpuse, kõnekäändude ja fraseologismide andmebaasi ning interneti-päringu vastused sageduse järgi kolme rühma: 1) kuni 20 vastust, 2) ligikaudu 50 vastust, 3) rohkem kui 10000 vastust. Registripõhiselt eristasime vastuste hulgas neli rühma: 1) kirjalik avalik keelekasutus eelkõige teadustekstides ja ilukirjanduses, 2) kirjalik redigeeritud argisuhtlus ajakirjanduse vahendusel, 3) kirjalik spontaanne argisuhtlus internetis ja 4) argivestlus murdekeeles.

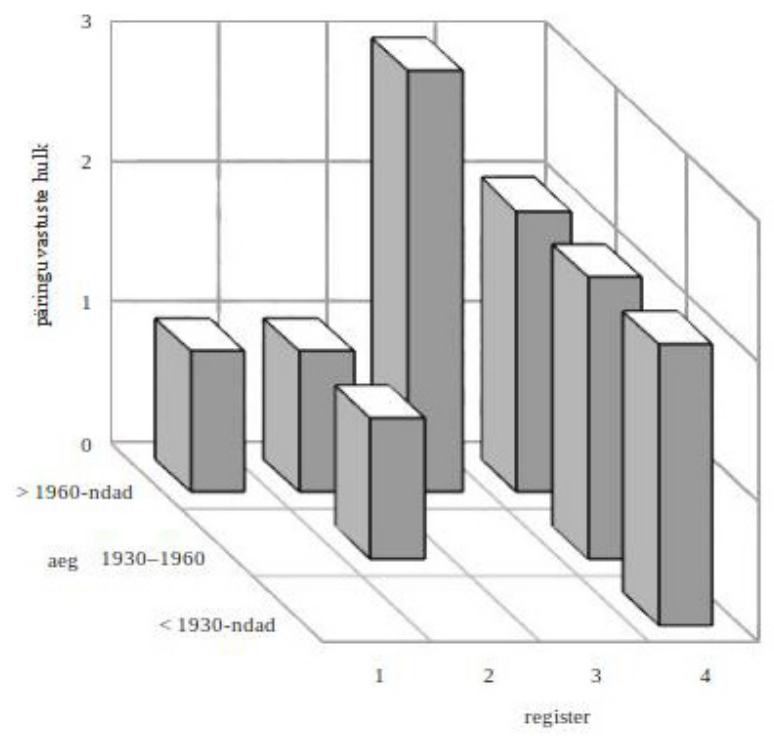

Diagramm 1. läheb nagu lepase lepse reega kasutussagedus, -aeg ja -situatsioon.

Näeme, et sõltumata ajalisest perspektiivist on ülekaalukalt tegu argikeele üksusega, mis on suulise suhtluse kõrval aja jooksul järjest enam aktsepteeritud 
ka kirjalikus vormis. Suure tõenäosusega iseloomustab see mudel suuremat osa tänapäeva eesti keeles kasutusel olevast vanema keele fraseoloogiast.

\section{Kvalitatiivsetest nihetest ree-ja kelgu-kujundis}

Ree- ja kelgu-ütlused on enamasti negatiivse tähendusega - väga tihti peetakse nendega silmas midagi miinusmärgiga seonduvat: vallaslast, hädas olemist, halbu elukombeid, halba suhtumist jne. Tüüpiliselt need väljendid eksplitsiitset hinnangumarkerit ei sisaldagi. Ilma kontekstita on tänapäeva keelekasutajal raske ära tunda näiteks ütlusega poeg isa kelgus (Saareste I: 394) kaasnevat taunitavat suhtumist. Teatavaid pidepunkte kõnealuste fraseologismide mõistmiseks annab teadmine, et regi ja kelk kui laia funktsiooniga veovahendid, mida kasutati pea aasta läbi, on seotud raske, vaevalise, väsitava tööga. Elu, eluraskuste, pereliikmete sarnasuse jms seostamine ree või kelguga näib jäävat eesti keeleala piiridesse, kusjuures eesti murretes on see üsna ühtlane ja üldine.

Prototüüpne ree või kelgu vedaja on hobune; kui seda tööd teeb väiksema veojõuga loom, siis ei suju töö soovitud kiirusega, asjad ei edene, lähevad halvasti. Kui hobuse asemel veab rege/kelku inimene, ei saa sellestki midagi head tulla (vt näidet 13).

(13) justkui kits kelgu ees 'kui mõni ettevõte kusagile ei kõlba' (Saa). Võtab hinda küll, aga sellegipärast on kits kelgu ees 'ta on sellegipärast vaene' (Kos); nagu jänesel peräregi takah 'linnainimesele talutöö' (Se); veab kelku 'valetab'

Kui lapsed käivad vanemate pereliikmete jälgedes, muutuvad nad vanade sarnaseks ja võivad üle võtta ka halvad kombed. Teisele inimesele kuuluvate asjade, olendite kasutamine mõistetakse üldjuhul hukka (vt näidet 14).

(14) Pojad on isa rees, isa kelgus 'pojad on isa sarnased halvas mõttes' (Wied). Ega seegi regi teise ree peale ei lähe 'noore tütarlapse kohta, kelle vanem õde on liiga vabade elukommetega' (Trt). Sõidab teise kelgus, rees, saanis 'mugatseb, elab teise arvel' (Kul). Noorest pääst on elbul old ja teiste kelkujel mäest alla last 'teiste kulul elanud' (Kuu). Tõise kelgu pääl istje oleme 'kaval olema, tõist oma kasus tüöd tettä ja vaeva nättä laskme' (Krk), vrd [kellegi] naha peal elama, [kellegi] turja peal liugu laskma, [kellegi] selga elama tulema, Mis viga teise pükstega tules istuda (EV 11867), Mis viga teiste hobustega sõita on (EV 11868). 
Mõnikord on veovahendinimetus täiendiga lähemalt iseloomustamata, kuid fraseologismi negatiivne alatoon kontekstis siiski selge (vt näidet 15).

(15) Küll ta vaene on nü̈̈d kelgus (Amb). Küll ma olin saadanaga kelgus (Tor). Täna olen kelgus 'täna olen omadega pigis' (Wied). Olin kaks nädalat ära ja poiss on ikka rees 'endiselt halvas seisus', vrd kelku panema 'kihlama': Emä tuli kodo ja ütles, Matsi-Mari panti kelku. Kui kõsjad õlid ärä juadud, panti kelku (Kod). Sööb ära, kõik paneb kelku 'paneb nahka' (Kod), kelgus (Saareste I: 564, mõiste hädas).

On loomulik, et ühes ja samas rees või kelgus istuvad inimesed sarnanevad millegi poolest üksteisega, nad võivad jagada mõttelaadi, hoiakuid, meelelaadi või olla ühevanad. Näidetes 16-18 on toodud erandlikumaid, s.o hinnangult neutraalseid fraseologisme.

(16) Sai teise oma kelgu peale 'sai teise oma nõusse' (Saa); Küll teie tu-

lete veel lõpuks minu ree peale 'küll teie tulete kord samale arvamisele, kui mina olen' (Jür); Tema tuleb minu ree peale 'toimib nagu mina' (MMg); Teie tulete ike minu kelgu piale, minä ei tule teie kelgu piäle mette 'nooredki kord vananevad ning muutuvad töövõimetuiks' (Kod, Pal).

(17) Kui ma tema kelku sain 'kui ta mind halvale teele, eksiteele viis' (Wied); Kirgu-i midägi uma nuurusõga, küll tult piä mii vannu rekke (Rõu); Kust sa nende kelku said?

(18) ühte kelku heitama 'ühte liiki või mesti heitma, ühes mestis olema' (Saareste II: 559); Ta on ses rees 'ses mestis' (Saareste II: 559); iga ree peal sõitma 'nina tuule järgi seadma, pärivoolu ujuma' (Wied); Ta on kurjas rees 'kurjas kambas' (Saareste II: 559).

Võib arvata, et algselt on läheb nagu lepase lepse reega kujundi fookuses olnud ree valmistamise materjal. Lepapuusse on vanasti suhtutud vastandlikult. Rahvausundilises maailmapildis on see arvatud pühakspeetavate puude hulka (vrd Pühalepa kihelkond Hiiumaal); lepale omistatavat maagilist mõjujõudu kasutati nii rahvameditsiinis kui ka tõrjevahendina (vt Hiiemäe 2004: 20 jj). Teisalt halvustati leppa pehme ja vastupidamatu puidu tõttu ning seda on nimetatud pasklepaks, seatammeks. Sedasama pehmust on ka hinnatud; kergesti töödeldavus oli oluline majapidamisriistade, eriti piima- ja võinõude, kausside jmt valmistamisel. Lepapuuga on hea liha või kala suitsutada. Lepa punane puit ja koor olid tähtsad looduslikud värvained, sellest ka kalalepp 'kalaveri', lepane 'verine', leppama, lepitama 'punaseks värvima', lepp 'ruuge 
hobune' (ES MA), lepalind, lepatriinu. Ometi ei ole lepa head omadused kujundina eesti keeles eriti realiseerunud. Ka reega seoses märgib lepane, lepne murretes midagi taunitavat ja seda vähemalt möödunud sajandi teise pooleni välja. Kujundi negatiivsus on mõistetav, sest regede ja reeosade valmistamiseks kasutati sootuks vastupidavamat kaske, saart, tamme, kuuse juurpuud (vt Viires 1980: 38-39, 60) vms ja mitte suhteliselt pehmet leppa. Sobimatus vastupidavust nõudvate esemete valmistamiseks oli praktilise maarahva silmis ilmselt kaalukas argument, et lepaga tähistada midagi kehva, viletsat, nõrka, närust, armetut jne (vt näiteid 19, 20) (Vakk 1984: 6, 7).

(19) No mis ta käu, lätt kah kui lepatse reega (Vas). Sai vedada lepase reega 'sai pilgata' (Jõe); nagu lepse reega üle sõitnud 'halvasti ja pealiskaudselt tehtud töö' (Lai); nagu lepse reega edasi minema 'viletsalt edasi jõudma' (Wied); lätt kui lepatse riiga haust aida pitti 'kui kuurma om viltu, ratta kehvä, kuurma rassõ' (Se); sõidab nagu lepatse riiga halva tiiga: viis päeva ja kolm versta (TMr). Kui keegi teist pilkas selle kohta öeldi, vedas teist lepakelguga (Mär); läks nagu lepise reega 'lepast ei tee ju keegi rege ja see ei püsi, kuid võrdlusel püsib see rapase töö kohta' (Vjg).

(20) üks kruu lepane, teine lehmasitane 'kelle mõistus pole täiesti korras' (Kuu); On lepase kruviga 'puuduliku mõistusega' (Lüg); See on ju lepase nikastanud nupuga 'kerge aruga inimese kohta, kes tühja juttu ajas' (Iis); Sie ôli ikke suuta leppane. Terve pere niisikesed leppased 'nõrga, vähese mõistusega' (Jõh).

Tänapäeval on läheb nagu lepase lepse reega kujundi fookuses pigem regi ja nagu teada tähendab ütlus algsega võrreldes vastupidi 'läheb libedasti, ladusasti, häireteta, tõrgeteta, jõudsasti' (vt EKSS, Fraseoloogiasõnaraamat). Kujund on ümber mõtestatud suhteliselt hiljuti. Seda on soodustanud lepa rahvausundilise maailmapildi hägustumine ja mentaliteedi muutumine, mis on M. Hiiemäe (2004: 21) andmetel toimunud 19. sajandi lõpukümnenditel. Isegi Feliks Vakal, kes on põhjalikumalt uurinud eesti fraseoloogia etümoloogiat, ei õnnestunud varasemate keeleteooriate najal siia selgust tuua. Kõige tõenäolisemaks pidas ta lihtsalt kujutluspildi ununemist ja tuhmumist (vt Vakk 1984: 6-8). EKFAs leidub 19. sajandi lõpu ja 20. sajandi algusega dateeritud üleskirjutisi, kus seda väljendit on kasutatud üheaegselt nii halvasti kui ka hästi edenemise kohta, sekka nn üleminekutähenduses 'kiiresti, aga mitte korralikult'. 20. sajandi algupoolel on ülekaalus juba tänapäeva eesti keele kõnelejaile teada tähendus; küll on fraseologismi algne sisu visamalt püsinud Lõuna-Eesti keelealal (vt näiteid 21-23). 
(21) lähäb nagu leppase riega 'kui üks asi õige libedast lähäb' (Iis, 1889); lätt kui lepätse reega 'halv elokõrd' (Vas, Se, 1894); Ta sõidab nigu lepatse riiga halva tiiga: viis päeva ja kolm versta (TMr, 1901).

(22) läheb kui lepise reega 'kui ruttu lohakat tööd tehakse' (Pst, 1937)

(23) Ta läts nii ku lepädse riiga 'kui midagi halvasti on tehtud' (Har, 1932); Lätt kui lepitse riiga haust aida pitti 'ku kuurma om vilto, ratta kehvä, kuurma rassõ' (Se, 1938).

Meie püüame seda tähendusmuutust põhjendada kognitiivse keeleteaduse võtmes: väljendi läheb nagu lepase reega taustsüsteemile ja liikumissündmuse motivatsioonile toetudes. Kesksel kohal on siin liikumine ja hinnang sellele.

\section{läheb nagu lepase reega mõistelisest taustsüsteemist}

\section{Ruumisuhted ja liikumine}

Teatavasti on inimese põhilisemaid tegutsemismooduseid oma keha vertikaalja/või horisontaalsuunal liigutamine. Näiteks prototüüpne kõndimine algab püstitõusmise ja kahel jalal seismisega, seisneb ruumis liikumises ning lõpeb kuhugi jõudmise ja seismajäämisega (vt ka nt Lemmens 2004: 5).

Ruumisuhetel rajanevad mõisted paigutuvad meie mõistesüsteemi keskmesse (arutluskäiku sellest vt eesti keeles Luuk 2008: 954 jj). Neid rakendatakse taju- ja mõistesüsteemide abil, kuid tajutakse loomulikult hoopis teisiti kui füüsilisi objekte. Enamik ruumisuhteid on komplekssed; elementaarsete ruumisuhete struktuuri on aga kaasatud kujundskeem, eend, trajektoor ja orientiir, s.o muutuja ja pidepunkt (vt nt Lakoff \& Johnson 1999: 30, 31). Näiteks eesti kaassõnade üle ja peale arvukate tähenduste aluseks selguvad olevat kujundskeemi võimalikud tee, katmise ja vertikaalne perspektiiv (vt Veismann 2004; 2006).

Ruumiloogika on omane ka lähe-tee-eesmärk skeemile, mis aitab meil mõista iseenda või mille tahes muu liikumist. Ruumisuhted on skeemi kaasatud implitsiitselt:

- olles jõudnud mingisse kohta, oled olnud ka kõigis vahepealsetes kohtades sellel teel;

- $\quad$ kui sa lähed Ast Bsse ja seejärel Bst Csse, siis oled läinud Ast Csse;

- $\quad$ kui Ast Bsse saab minna otse ja sa liigud mööda seda teed B poole, siis jõuad Ble lähemale;

- $\quad$ kui X ja Y sõidavad otse Ast Bsse ja X möödub Yst, siis X on Ast kaugemal ja lähemal Ble kui Y; 
- $\quad$ kui Xja Y hakkavad üheskoos mööda sama teed Ast B poole minema ja X liigub kiiremini kui Y, siis X jõuab Bsse rutem kui Y (Lakoff \& Johnson 1999: 33 jj; vt ka Johnson 1990: 113, 114).

Kuna tõenäoliselt kasutab mõistesüsteem meie sensoorse ja motoorse süsteemi olulisi osi (Lakoff \& Johnson 1999: 38, 39), siis Srini Narayanani (1997) liikumisskeemide (motor schemas), aspekti ja metafoori mudeli kohaselt on kõigil liikumisskeemidel sama ülemtasandi struktuur. Mis tahes ülemtasandi liikumistegevusse kuuluvad

- valmiduse seisundisse minemine;

- algseisund;

- alustamise protsess;

- (silmapilkne või pikemaajaline) põhiprotsess;

- võimalus lõpetada;

- võimalus uuesti teha;

- võimalus põhiprotsessi korrata või jätkata;

- kontrollimine, kas eesmärk on saavutatud;

- lõpetamise protsess;

- lõppseisund.

Põhimõtteliselt iseloomustab see mudel sündmuste semantilist stuktuuri aspekti. Needsamad närvistruktuurid, mis kontrollivad liikumist, võivad iseloomustada aspekti mõistelist struktuuri. Needsamad närvimehhanismid, mis kontrollivad füüsilist liikumist, võivad aidata teha loogilisi järeldusi tegevuste kohta üldiselt (Lakoff \& Johnson 1999: 41, 42, 581, 582).

Tulenevalt nii väljendi läheb nagu lepase reega diakrooniliselt varasemast kui ka hilisemast tähendusest, tõusevad meie artikli huvikeskmesse lisaks tee kujundskeemile horisontaalsus (mis avaldub inimese jaoks ehk selgeimalt lebamises (vt Lemmens 2006: 266 jj)) ning tegevuse piiritletus (vt näidet 24). Kuna maastiku pinnamoe ja liikuja füüsilise tasakaalu vahel on sensoorne ja motoorne vastavus, mängib ütluse mõistmisel teatud osa veel tasakaal.

(24) Esimese päeva jooks reedel oli lühike ja kiire: 10 kilomeetrit sujus tänu kodusele toidule ja hästi läbi mõeldud treeningule nagu lepase reega. Väljas on pea +7 , lumi läheb nagu lepase reega üle Eesti, ehk Haanja peab ainsana vastu. Meie lombine asfalt kipub päris tihti hilissügisel ööseks jäätuma ja siis läheb nagu lepase reega. Kui kasutusel on uuem Windows ja Internet Explorer, peaks kõik sujuma automaatselt nagu lepase reega. Enne valimisi ei olnud mingit sisulist debatti 
siseturvalisuse üle, kõik oli kuidagi korras, rahulik ja vaikne ning läks justkui lepase reega.

Horisontaalsus ilmneb antud juhul eelkõige eesmärgi ja tee kaudu. On loomulik, et et horisontaalsuunal on inimesel tohutu pideva liikumise kogemus - horisontaalsuunal saab tegevus kesta, muutuda, pöörduda, mida näitavad m.h eesti horisontaalse suuna adverbide abstraktsed tähendused (vt Veismann \& Tragel 2008: 521 jj). Samas ei tähenda see, et horisontaalsuunal aspektivõimalus puuduks. Kuigi läheb nagu lepase reega paistab põhiliselt väljendavat kestvat edenemist, võib väljendi kontekstis sageli tajuda tulemuslikkust või lõpetatust. Nagu teada, ei ole tegevuse resultatiivsuse ja piiritletuse/piiritlematuse täpsustamisel eesti keeles oluline mitte niivõrd kontekst kui selline, vaid just konteksti kui terviku, s.o lause, lauseülese konteksti, tekstilõigu, tervikteksti semantika. Teksti tasandil võidakse tegevuse resultatiivsust väljendada erinevate keeletasandite omavahel põimunud vahenditega, näiteks kausatiivsusega: nuttis end magama, laps karjus end higiseks, verbi valentsiga: töötati õhtuni, raamat lagunes kapsaks, tõusid kõrgele, asetas taha, mattis kinni (Eslon \& Pihlak 1993: 50, 51). Eesti keeles ongi aspektuaalsus hajutatud verbi laienditele, k.a selle käändevormid, $d a$-infinitiiv, adverbid (Eslon \& Pihlak 1993: 51).

\section{Hinnang sündmusele}

Sündmuste tajumine ja interpreteerimine sisaldab väga tihti vaikimisi hinnangut tehtu kvaliteedile või tulemustele. Kui me midagi teeme, siis enamasti ikka millegi saavutamiseks: karjääri eesmärk on saada hea töö ja teenida palju raha, kellegagi võisteldes soovime tingimata võita jne (Langlotz 2006: 144). Seatud eesmärki saavutada või vähemasti selle poole liikuda aitab nii tegutsemine kui ka selleks valitud vahendid ja meetodid. Kui viimased on adekvaatsed ning sooritus kvaliteetne, osutub tegevus edukaks. Seda, kas tegevuse tulemus on edu, progress või hoopis ebaõnnestumine, võivad mõjutada veel sellised positiivsed või negatiivsed tegurid nagu abi ja tugi, probleemid ja häired, samuti tegevuse välised tingimused.

Edu ja ebaõnnestumise fookuses on tegevuse tulemus või tegevusega saavutatud seisund. Kui eesmärk on saavutatud, oleme edukad; kui eesmärk jääb saavutamata, oleme järelikult ebaõnnestunud. Progressi, stagnatsiooni ja regressiooni fookuses on aga tegevuse arenemine ajas. Kui me läheneme eesmärgile, siis asi edeneb; kui me eesmärgile ei lähene, räägime seisakust või taandarengust. Kuna edasiminek viib tõenäoliselt positiivse tulemuseni, on progress konventsionaalselt seotud eduga, stagnatsioon ja regressioon ebaõnnestumisega 


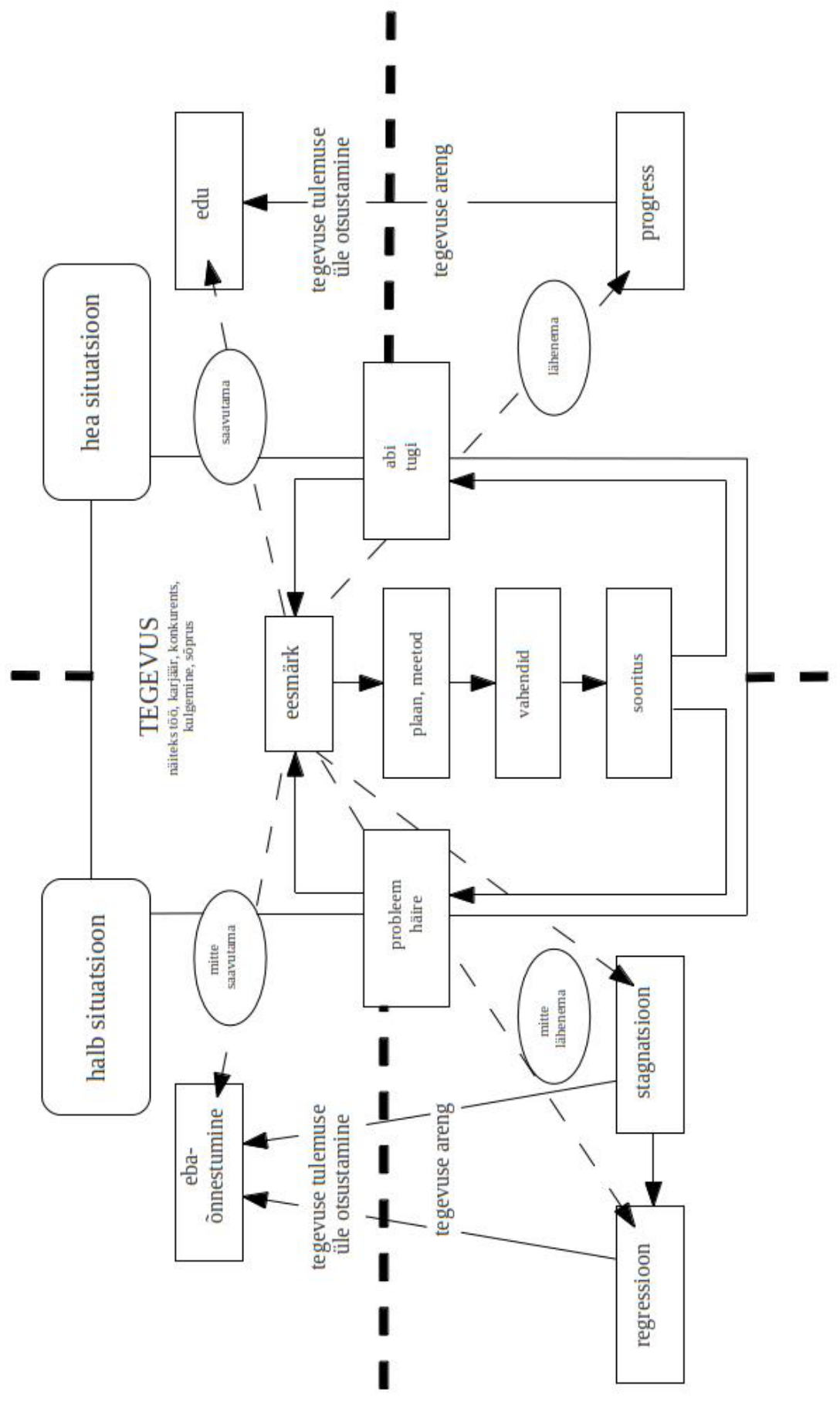

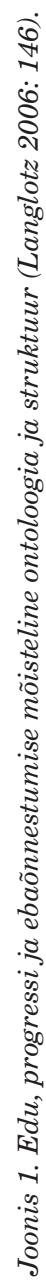


(Langlotz 2006: 145). Andreas Langlotz (2006) on Collinsi fraseoloogiasõnaraamatu põhjal uurinud 600 briti inglise keele idioomi, mis tähendavad edu, progressi või ebaõnnestumist. Enamikku neist väljenditest võib seostada kuue üldise allikvaldkonnaga: võistluse, võitluse, elu, söömise, füüsilise liikumise ja masina spetsiifilised struktuurid ja ontoloogiad kantakse üle edu, progressi ja ebaõnnestumise sihtalale et viimaseid liigendada, mõistestada ja täpsustada. Vastavalt mõistete edu ja progress versus ebaõnnestumine, stagnatsioon ja regressioon semantilise väärtuse kujunemisele, moodustab nende abstraktse mõistelise aluse joonisel 1 esitatud üldine valdkond (Langlotz 2006: 145).

\section{Liikumissündmuse võimalik motivatsioon ja struktuur}

Väljendi nagu lepase reega ning teiste ruumi- ja liikumissüsteemi samasse osasse kuuluvate keelendite puhul saame rääkida üsna selgest motivatsioonist, mille käivitavad mõistemetafoorid muutus on liikumine ja progress, arenemine on edasiliikumine, ning mida võivad aidata kujundada metonüümsed seosed, sümboolsed assotsiatsioonid ${ }^{4}$ ja mõisteline sulandumine (vt Langlotz 2006: 148). Mis tahes inimlik sündmuste ja põhjuste tõlgendamine toetub põhiliselt komplekssele sündmuse struktuuri metafoorile. Seejuures võidakse sündmusi ja selle aspekte (tegevusi, põhjuseid, muutusi, seisundeid, eesmärke jne) mõistestada asukohtade või objektide kaudu (vt vastavalt näiteid 25 ja 26).

(25) Kaotajate poolel hoidis oma tiimi ree peal Martti Varusk 26 punktiga.

(26) Võtta teine rong. Eestis näib valitsevat arvamus, et meie talupidajatel õnnestub Euroopa Liidus ellu jääda ainult suurtootmise abil.

Siin on abiks need arvukad kogemused ja teadmised, mis meil on ruumis liikumise kohta. Mõlemal juhul kasutatakse primaarseid metafoore põhjused on jõud ja muutus on liikumine (Lakoff \& Johnson 1999: 178, 179). Sündmuse struktuuri asukoha-metafoori kohaselt

- $\quad$ on seisundid asukohad (piiratud alad ruumis);

- muutus on liikumine (piiratud alale või piiratud alalt);

- põhjused on jõud;

- põhjustamine on forsseeritud liikumine (ühest kohast teise);

- tegevused on iseeneslikud liikumised;

- eesmärgid on sihtpunktid;

- vahendid on teed (sihtpunktide suunas);

- raskused on liikumistakistused; 
- tegutsemisvabadus on liikumistakistuste puudumine;

- eeldatav areng on sõiduplaan;

- sõiduplaan on virtuaalne reisija, kes jõuab plaanitud ajal plaanitud kohta;

- $\quad$ välised sündmused on suured liikuvad objektid;

- pikaajalised eesmärgistatud tegevused on teekonnad (Lakoff 2006: 204; Lakoff \& Johnson 1999: 178, 179).

Mida sellest täpsemalt järeldada? Nagu teada, peab edu saavutamiseks areng kõigepealt algama - see hõlmab lahkumist lähtepunktist (vt näidet 27; lähtekoha keelendamisest eesti keeles vt Pajusalu jt 2008: 7-11). Kui valitud on vale või liiga ambitsioonikas meetod, suund, võib tegevus alata vaevaliselt ja päädida ebaõnnestumisega. Seepärast tuleks enamasti alustada aeglaselt (näide 28) (Langlotz 2006: 157, 158).

(27) Riigikaitsemudeli kujunemisraskustest taasiseseisvumise stardipakul.

(28) Sõi selle ära ja ääri-veeri küsis, et kas äkki oleks veel.

Edasi sõltub tegevuse edukus valitud teest, millega on omakorda tihedalt seotud liikumisviis (vt Pajusalu jt 2008: 11). Metafoori allikmõiste tee võimaldab arengu sihtmõistes eristada suunda ja tingimusi, milles tegevus aset leiab. On selge, et tee, mis viib soovitud sihtpunkti, aitab edasi areneda. Vastasel juhul on see ebaefektiivne või takistab tegevust (vrd näiteid 29, 30) (Langlotz 2006: 158).

(29) Naiseisa avitas ta ôtsa piale. Nü̈̈d tal omal loomakari laadas (Trm).

(30) Efektiivsuse suurendamine pole iseenesest vale, aga ainult sellele keskendumine on pikas perspektiivis ummiktee.

Kui järgida selle metaforisatsiooni loogikat, näeme näites 31 agendi kõrvalekaldumist õigelt teelt - ebaõnnestumise põhjust (vt lähemalt ka K. Õim 2007). Teel püsimine väljendab aga edukat arengut ja uue tee valimine positiivse arengu tõenäosust (vt näiteid 32, 33) (Langlotz 2006: 158).

(31) Lugu allakäinud maadlejast, kelle elu rööbastelt maha on sõitnud.

(32) Sebastien Loeb jätkab ka pärast teist võistluspäeva kursil Küprose ralli võidu suunas. Seni andsime abi rea peal seismiseks, nü̈̈d koolitus enam tulevikku suunatud. 
(33) Peamine stiimul tõusuks saadi asjaolust, et musta kulla hind pööras otsa ringi.

Tegevuse seisukohalt (eba)soodsaid tingimusi aitavad konkretiseerida tee omadused: sile tee tähistab progressi ja edu soosivat konteksti (vt näidet 34). Raske, ohtlik ja ebameeldiv tee takistab arengut ning võib viia ebaõnnestumisele, mistõttu tuleb edu tagamiseks midagi ette võtta (näited 35, 36) (Langlotz 2006: 158).

(34) Tema elutee on olnud üsna sile (EKSS).

(35) Kui mõni sandiste loeb, see läheb na üle küngaste puha (Kuu). Mõne lugemine one nõnnagu söödi künmine, mukko jajatab (Kod); nagu regi liiva peal kinni 'kinnine või saamatu oma töös või teos' (Saa). See on tü̈̈pilise emotsionaalse liialdaja käekiri, kes loogiliste argumentide puudumisel on asunud demagoogia libedale teele. Ei see kristlase tee pole sile ja sirge.

(36) Kõik see sillutab Linuxi teed UNIXi asendamisel. Liikmesriikide kohustus kõrvaldada takistused elektrooniliste lepingute kasutamisel.

Liikumine mööda teed sihtpunkti poole väljendab lähenemist eesmärgile. Mida pikem vahemaa on läbitud, seda lähemal on edu, isegi kui selleks tuleb spetsiaalselt pingutada (vt näidet 37). Kui liikujad on väga kiired ja konkurentsivõimelised (vrd eesmärgipärane tegevus on võidujooks), võivad nad sihile jõuda tunduvalt varem kui teised. Ja vastupidi: areng stagneerub või regresseerub, kui agent ei liigu edasi või liigub ringiratast (näide 38) (Langlotz 2006: 158, 159).

(37) Pärnu finantskonverents on lähedal, täpsemalt nädala pärast 17.-18. aprillil. Tänu kaubanduse jõudsale arengule loodavad ehitajad, et investeering teeb end tasa kahe-kolme aastaga.

(38) Ja võib arvata, et ka Ekspressi aktsia teeb algul vähikäigu, ning siis tammub paigal. See on pannud ka mind mõtlema, kas oleme tagasi Moskva ajas.

Agendi seisukohalt on edu eelduseks tema käte-jalgade konstitutsioon või koordineeritud liikumine. Näites 39 kombineerub metafoorne ülekanne (arenemine on edasikõndmine) metonüümsega (jalg kõndimisvõime asemel). Nurjumist mõistetakse vastavalt kui komistamist või kukkumist - igal juhul kui mittekoordineeritud liikumist (näide 40) (Langlotz 2006: 159). 
(39) Seda, et ta oli kerge jalaga, võeti arvesse ametisse kinnitamisel (Trm). See majapidamine lonkab küll kahe jalaga (Iis).

(40) Ninda aigased nied suvitajad, ei jõuva päist jalgu mitte kuhugi (Lüg). Minu meeskond sebis nagu kanad takus. Kuna vahepeal takerdusid detailplaneeringu koostaja otsingud ...

See, kes reisib, sõltub jalanõudest või kasutab kiiremini edasi liikumiseks transpordivahendit. Olenevalt väljendite aluseks olevast konkreetsest teekonnafreimist, võidakse neis eksplitsiitselt osutada mõnele transpordivahendile. See allikvaldkond on üle kantud sihtvaldkonna mõistelistele elementidele (tõhusad vahendid või meetodid, abi või soodustavad situatsioonid), mis toetavad progressi. Seega täpsustab metafoor arengu tugi on transpordivahend ideed, et areng on tõhusam, kui seda soodustavad välised mõjurid. Transpordivahendile (mitte) asumine korreleerub vastavalt selle võimaluse (mitte)kasutamisega (vt näidet 41). Kui transpordivahend liigub, saab lühikese ajaga läbida pika vahemaa ja seega on progress tagatud; kui transpordivahend ei liigu korralikult või efektiivselt, areng pidurdub (näide 42). Järelikult tuleb ebasobiv transpordivahend, mis konkretiseerib ebaefektiivseid vahendeid või meetodeid, probleeme või situatsioone, kohandada väliste tingimustega või sellest loobuda (näide 43) (Langlotz 2006: 159, 160).

(41) Kohvitehas surfas taas lainele. Kes on aidanud paljudel sõltlastel tagasi ree peale saada. Kuigi Euroopa Liit meenutab pahatihti varjuteatrit, oleme lunastanud pileti stabiilsesse mõnusasse rongi ja paanikaks pole põhjust, leiab Martin Kala. Leedu jääb Schengeni rongist maha.

(42) ei lähe enam regi ega ratas 'sandi tee aegas' (Tõs); ei veere vanker ega jookse regi (Kuu); ei see kelk joose jaanipäävase jää peal 'kes teistele tahab oma valet usutavaks teha' (Rap, Mär)

(43) Kruuda ja Kangur tõmbasid Aava MM-sõitudele piduri peale. Mõistlik oleks rong peatada.

Peale tee halva seisukorra, mittekoordineeritud liikumise või transpordivahendi ebaefektiivse kasutamise võivad otseteed sihtpunkti takistada veel tõkked, takistused ja hädaohud. Takistuse mõisted kantakse üle sihtalale, tähistamaks probleeme: probleemid on takistused. Teada ohtlik teekond on näiteks reis üle mere, teel sihtpunkti võivad laeva ohustada tormid, karid, mõõnad. Vee mõisteline samastamine ebapüsivusega teeb merereisi riskantseks. See 
teadmine sisaldub väljendites, milles iseloomustatakse probleeme või keerulisi situatsioone kui võimalikke ohtusid (vt näidet 44). Transpordivahendiga kattub osaliselt masin, mis tekitab kujutluse mehhaniseeritud transpordivahendist kui arengumudelist (näide 45) (Langlotz 2006: 160, 161).

(44) Nii elulaev vahest karile jooksebki 'vahel läheb halvasti' (Sim). See on vaikus enne tormi: maja mü̈̈akse kiiresti ja vaikselt Tallinna Hambapolikliinikuga ühes majas asuvale Kaarli Hambapolikliinikule.

(45) Põlevkiviga köetav auruvedur kõrvalteele lükata, moodsa ja kiire elektrirongiga edasi sõita.

Taolisi, suhteliselt vaese struktuuriga sihtmõisteid nagu edu, progress või ebaõnnestumine aitavad täpsustada kõige põhilisemad kujundskeemid. Näiteks vertikaalsuse, tasakaalu jm skeemid aitavad meil orientatsiooni ja tasakaalu kogemuse põhjal konstrueerida hinnangulisi mõisteid hea või halb, positiivne või negatiivne. Inimese kehalises kogemuses on tasakaalu ja tasakaalustamatuse sensoorne ja motoorne aisting seotud tegevuse õnnestumise või ebaõnnestumisega. Siit tuleb metafoori positiivne areng on tasakaal, negatiivne areng on tasakaalustamatus kogemuslik põhialus. Tasakaalu-metafoor on omakorda väga tihedalt seotud metafooriga arenemine on liikumine. Kui me kõnnime, mõjutab maastik otseselt meie füüsilist tasakaalu. See sensoorne ja motoorne vastavus motiveerib osaliselt konstruktsioone turvalisus või stabiilsus on kõva maa, ebaturvalisus või ebastabiilsus on vesi, ebaturvalisus või ebastabiilsus on õhk (Langlotz 2006: 161 jj).

\section{Kokkuvõtteks}

Väljend läheb nagu lepase reega, mille kujunemist võib dateerida vastava veovahendi kasutuselevõtuga Eestis, on tänapäeva eesti keeles väga levinud. Seda nii suulises kui ka kirjalikus argisuhtluses. Algselt oli selle fraseologismi kujundi fookuses tõenäoliselt ree valmistamise materjal ja ütlus tähendas negatiivset ('halvasti edenema' vms) nii nagu enamik teisigi ree-ja kelgu-ütlusi. Suhteliselt lühikese aja jooksul on kujundi keskmesse nihkunud regi ja väljendi tähendus muutunud positiivseks ('hästi edenema' vms). Kindlasti on kujundi ümbermõtestamises oma osa mänginud lepapuu mentaliteedi muutumine, kuid meie otsisime selle tähendusmuutuse põhjuseid kujunditekke taustsüsteemist ja liikumissündmuse motivatsioonist. 
Inimkeha või mis tahes muu objekti vertikaal- ja/või horisontaalsuunal liikumist aitab mõista lähe-tee-eesmärk kujundskeem, millel on selge ruumiloogika. Kuna usutavasti kasutavad inimesed mõistesüsteemi puhul oma sensoorse ja motoorse süsteemi olulisi osi, siis võib kõigil liikumisskeemidel olla sama ülemtasandi struktuur. Needsamad närvistruktuurid, mis kontrollivad liikumist, võivad iseloomustada sündmuste semantilist struktuuri. Needsamad närvimehhanismid, mis kontrollivad füüsilist liikumist, võivad aidata teha järeldusi sündmuste kohta üldse. Sündmuste tajumine ja tõlgendamine sündmuse struktuuri metafoori põhjal võib hõlmata vaikimisi hinnangut tehtu kvaliteedile või tulemustele. Tegutsedes on võimalik saavutada endale seatud eesmärk või liikuda selle poole. Seda, kas tegevuse tulemus on edu, progress või on selle tagajärjeks ebaõnnestumine, võivad mõjutada kasutada olevad vahendid ja meetodid, abi ja tugi, tegevuse käigus ette tulevad probleemid ja häired.

Läheb nagu lepase reega suhteliselt selge motivatsiooni käivitavad mõistemetafoorid muutus on liikumine ja progress, arenemine on edasiliikumine. Tulenevalt selle väljendi aluseks olevast teekonna-freimist, on siin eksplitseeritud transpordivahend. Nimetatud allikvaldkond on üle kantud sihtvaldkonna mõistelistele elementidele, mis toetavad progressi: vahendid või meetodid, abi või soodustavad situatsioonid. Areng on suurem, kui miski seda soodustab, seega arengu tugi on transpordivahend. Kui transpordivahend liigub, saab lühikese ajaga läbida pika vahemaa ja sellega on progress tagatud; kui transpordivahend ei liigu korralikult, areng pidurdub. Kuna eesmärgini jõudmist või selle poole liikumist väärtustatakse üldiselt positiivselt, siis on artiklis analüüsitud konstruktsioonis negatiivset tähendust markeeritud spetsiaalselt - täiendiga. See, et tänapäeval tunneme väljendit vastupidises tähenduses, näitab nimisõna laiendi allumist domineerivale, s.o liikumissündmuse struktuurist lähtuvale tõlgendusele. Neid muutusi võib olla soosinud see, et kirjeldatud, hästi läbi paistev motivatsioon rakendub eesti keeles hinnanguliselt suhteliselt harva. S.t transpordivahend kui ehk liiga konkreetne ja tagasihoidliku struktuuriga, väheproduktiivne allikmõiste on jätnud antud semantilises piirkonnas nii põhimõttelisteks tähendusmuutusteks piisavalt ruumi, võimalusi. Niisiis võiksime seda, mis on ütlusega läheb nagu lepase reega aja jooksul toimunud, pidada täiesti süsteemipäraseks ja põhjendatuks. Seda, et väljendi areng ei ole kirjeldatuga veel sugugi lõppenud, kinnitab piiritletud aspekti tähenduse kaasnemine selle fraseologismiga tänapäeva eesti keeles. 


\section{Kommentaarid}

1 Artikkel inglise keeles: Õim, Katre \& Õim, Asta 2010. Qualitative Changes in Phraseology: General Principles and Catalysts. Linguistica Uralica 46 (1), lk 17-37 (doi: 10.3176/lu.2010.1.02, http://www.kirj.ee/public/Linguistica_Uralica/2010/issue_1/ling2010-1-17-37.pdf).

${ }^{2}$ Lepase kui ebakvaliteetsuse võrdkuju jälgi leiame seostatult reega näiteks põhjavepsa laulus, kus bat'eiž ajab koivheižir kordeižiл, l'epheižir reguźiл (Tiit-Rein Viitso suuline teade) ning Tveri Karjalast: elä pilkkua keyhän kelkkua, leppäni on oma reges 'ära pilka vaese kelku, lepane on su oma regi' (vt Karjalan kielen sanakirja). Läti keeles võidakse öelda viņa karjera iet lejup kā ragavas no kalna 'tema karjäär läheb alla nagu regi kelk mäest'. (Aitäh Silja Grünbergile ja Lembit Vabale!)

3 90\% EKFA materjalist pärineb käsikirjalistest allikatest, s.t tegu on keelejuhtide suulise kõnega. Artiklis on EKFAst pärit keelekasutuse näidetele lisatud kihelkonnalühend.

${ }_{4}$ Maailmateadmuse ja nn kultuuriteadmuse eristamisest vt nt Piirainen 2008.

\section{Allikad}

Eesti Kirjakeele Korpus 1890-1990 (http://test.cl.ut.ee/korpused/baaskorpus/ - 2. mai. 2012).

Eesti kõnekäändude ja fraseologismide andmebaas 1998-2005. Koost. Anneli Baran, Anne Hussar, Asta Õim, Katre Õim (http://www.folklore.ee/justkui - 3. mai 2012).

Eesti murrete korpus (http://www.murre.ut.ee/ - 3. mai 2012).

EKSS = Eesti kirjakeele seletussõnaraamat I-VII. Tallinn: Eesti Keele Instituut, 19882007.

ES MA = Emakeele Seltsi murdearhiiv.

\section{Kirjandus}

Eslon \& Pihlak 1993 = Eslon, Pille \& Pihlak, Ants. Vid i vremia . Trudy po sopostavitel'notipologicheskomu issledovaniiu raznosistemnykh iazykov. Tallinn: Tallinnskii pedagogicheskii universitet.

EV = Hussar, Anne \& Krikmann, Arvo \& Norman, E \& Pino, Veera \& Sarv, Ingrid \& Saukas, Rein (koost) 1980-1988. Eesti vanasõnad I-V. Tallinn: Eesti Raamat. 
Hiiemäe, Mall 2004. Lepp - lepakarva puu. Eesti Loodus 12, lk 20-22.

Johnson, Mark 1990. The Body in the Mind: The Bodily Basis of Meaning, Imagination, and Reason. Chicago \& London: The University of Chicago Press.

Karjalan kielen sanakirja 1983. Kolmas osa L-N. Kotimaisten kielten tutkimuskeskuksen julkaisuja 25; LSFU 16, 3. Helsinki: Suomalais-ugrilainen seura.

Lakoff, George \& Johnson, Mark 1999. Philosophy in the Flesh. The Embodied Mind and Its Challenge to Western Thought. New York: Basic Books.

Lakoff, George 2006 [1993]. The Contemporary Theory of Metaphor. Geeraerts, Dirk (toim). Cognitive Linguistics: Basic Readings. Berlin \& New York: Mouton de Gruyter, lk 185-238.

Langlotz, Andreas 2006. Idiomatic Creativity: A cognitive-linguistic model of idiom-representation and idiom-variation in English. Amsterdam \& Philadelphia: John Benjamins.

Lemmens, Maarten 2004. Metaphor, image schema and grammaticalisation: a cognitive lexical-semantic study. Université Lille III \& UMR 8528 SILEX du CNRS, France. Journée d'Études Grammar and figures of speech, Univ. Paris 3, 27/02/2004 (http:// www.google.com/url?sa=t\&rct=j\&q=\&esrc=s\&source=web\&cd=1\&ved=0CCMQFjAA\&u $\mathrm{rl}=\mathrm{http} \% 3 \mathrm{~A} \% 2 \mathrm{~F} \% 2 \mathrm{Fperso}$. univ-lille3.fr\%2F mlemmens $\% 2$ Fabstracts $\% 2 \mathrm{Fabstrengpos}$ diachr.PDF\&ei=EOAwT9jXGM6F-wb68uiLBg\&usg=AFQjCNHUmXkNJ1cMWQIFVZa BLwmteOaplA - 4. mai 2012)

Lemmens, Maarten 2006. Caused posture: Experiental patterns emerging from corpus research. Gries, Stefan Th. \& Stefanowisch, Anatol (toim). Corpora in Cognitive Linguistics: Corpus-Based Approaches to Syntax and Lexis. Berlin \& New York: Mouton de Gruyter, lk 261-296.

Lonin, Rürik 2000. Minun rahvhan fol'klor. Petroskoi: Periodika.

Luuk, Erkki 2008. Semantilised tasandid ja semantilised primitiivid. Keel ja Kirjandus 12, lk 949-967 (http://keeljakirjandus.eki.ee/949-967.pdf - 4. mai 2012).

Mägiste, Julius 2000. Estnisches Etymologisches Wörterbuch I-XII. 2. Auflage. Helsinki: Suomalais-Ugrilainen Seura.

Melentjeva, L’udmila \& Zaitseva, N. G. 1994. Soitoine. Vepsän randan lapsiden pajod. Petroskoi.

Narayanan, Srinivas Sankara. 1997. Knowledge-based Action Representations for Metaphor and Aspect (KARMA). Ph.D. Dissertation, Department of Computer Science, University of California, Berkeley (http://www.icsi.berkeley.edu/ snarayan/thesis.pdf - 4. mai 2012).

Pajusalu, Renate \& Kahusk, Neeme \& Orav, Heili \& Veismann, Ann \& Vider, Kadri \& Õim, Haldur 2008. The encoding of motion events in Estonian. Dimitrova-Vulchanova, Mila \& van der Zee, Emile (toim). Motion Encoding in Language and Space. Oxford University Press, lk 1-30 (http://www.google.com/url?sa=t\&rct=j\&q=\&esrc=s\&source =web\&cd=1\&ved=0CCMQFjAA\&url=http $\% 3 \mathrm{~A} \% 2 \mathrm{~F} \% 2 \mathrm{Fwww} . \mathrm{hf}$.ntnu.no $\% 2 \mathrm{Fmotionen}$ codingfiles $\% 2$ FMotionProject $\% 2$ Fbook $\% 2$ FEncoding $\% 2520$ of $\% 2520$ motion $\% 2520$ even 
t\%2520in\%2520Estonian_new_vers.pdf\&ei=c-EwT6m1CpDn-gbe6sXHBQ\&usg=AFQj CNH4eorTpK8Sip9lkH_p5exz9dWZkw - 4. mai 2012).

Piirainen, Elisabeth 2008. Figurative phraseology and culture. Granger, Sylviane \& Meunier, Fanny (toim). Phraseology: An interdisciplinary perspective. Amsterdam \& Philadelphia: John Benjamins Publishing Company, lk 207-228.

Saareste, Andrus 1958-1963. Eesti keele mõisteline sõnaraamat I-VI. Stockholm: Vaba Eesti.

Vakk, Feliks 1984. Miks just nõnda? Peotäis tekkelugusid ja uudistavaid lühimatku eesti fraseoloogia radadelt. Tallinn: Valgus.

Veismann, Ann 2004. Sõna üle tähendustest. Keel ja Kirjandus 10, lk 762-777.

Veismann, Ann 2006. peale ja pärast. Erelt, Mati (peatoim) \& Sepper, Maria-Maren (tegevtoim). Emakeele Seltsi aastaraamat 51 (2005). Tallinn, lk 170-183.

Veismann, Ann \& Tragel, Ilona 2008. Kuidas horisontaalne ja vertikaalne liikumissuund eesti keeles aspektiks kehastuvad? Keel ja Kirjandus 7, lk 515-530.

Viires, Ants 1980. Talurahva veovahendid. Baltimaade rahvapäraste põllumajanduslike veokite ajalugu. Tallinn: Valgus.

Wiedemann, Ferdinand Johann 1973. Eesti-saksa sõnaraamat. Tallinn: Valgus.

Õim, Asta 1993. Fraseoloogiasõnaraamat. Tallinn: Eesti Keele Sihtasutus.

Õim, Asta 2005. ree- ja kelgu-kujundist eesti fraseoloogias. Erelt, Mati (peatoim) \& Sepper, Maria-Maren (tegevtoim). Emakeele Seltsi aastaraamat 50 (2004). Tallinn, lk 143-158.

Õim, Katre 2007. Metafoor elu on teekond ebaõnne-väljendites. Erelt, Mati (peatoim) \& Erelt, Tiiu (toim). Emakeele Seltsi aastaraamat 52 (2006). Tallinn, lk 179-194.

\section{Summary}

\section{Qualitative Changes in Phraseology: General Principles and Catalysts}

Katre Õim, Asta Õim

Key words: Estonian, aspect, cognitive linguistics, conceptual metaphor, image schema, motion event, phraseology

The article observes the qualitative change of lexical units as a natural part of the language development process. The authors aspire to explicate the regularities in the changes that the meaning of phraseological expressions has undergone. This is performed on the example of the phrase läheb nagu lepase reega 'goes as on an alder sleigh' - an 
etymologically old and genuine phrase that is popularly used in Estonian dialectal, colloquial and literary language and whose semantic meaning has been subject to the largest possible qualitative change. The reconceptualization of the motif can be explained by the context of the image formation and the cognitive motivation of the motion event. 